\title{
Listening to care experienced young people and creating audio-bites for social work education
}

Lucas, S.E. and Thomas, N. (2020)

\section{ABSTRACT}

It can be challenging to incorporate young people's voices into social work pedagogy even though service user involvement is an essential part of social work education. Technological advances present new ways to involve service users and overcome barriers to participation. The purpose of this research was to explore service user involvement amongst young people by developing an audio resource for a qualifying social work programme in Scotland. We used a co-production methodology to create eight audio-bites based on interviews with four careexperienced people, aged 14-19, about their involvement with social work. We share key findings from the interviews, about the young people's involvement with social work and about being 'subjects' of statutory recording practices and processes, such as chronologies and Child's Plans. We discuss how the audio-bites were used in teaching and present feedback from students and lecturers about their use. We argue that the audio-bites promote authentic learning as they depict real life practice situations, and help students to develop listening and reflection skills that will inform their preparation for practice with children and young people.

\section{Introduction}

The inclusion of service user and carers' experiences and viewpoints are a mandatory part of social work training in Scotland (Scottish Executive, 2003). However, it can be challenging to incorporate young people's voices into pedagogy. In this article we report on research that demonstrates how we overcame this gap in one higher education institution by creating 8 audio-bites, based on care experienced young people's lived experiences. For brevity, we use the acronym 'SUCl' when discussing service user and carer involvement. The term 'service user' is used to cover the wide and diverse group of individuals who are involved in, or who use social work services. We use the terms 'children' and 'young people' 
to refer to individuals up to age 26 who have experience of being 'looked after' (Children and Young People (Scotland) Act, 2014).

Despite a general increase in service user and carer involvement ( $\mathrm{SUCl}$ ) in social work education in the UK, this has largely been the representation of adults, and young peoples' involvement remains limited (Lightfoot \& Sloper, 2003). This is perhaps sur- prising given that social work with children and young people are the mainstays of social work practices, with 59\% of newly qualified social workers employed in Children's Services (Grant et al., 2017). The structural, ethical and logistical barriers to engaging young people in social work education highlighted by Boylan et al. (2010) include that adults may be assumed to be more interested in sharing life experiences than children and young people, leading to limited involvement of young service users in education. The observation that children and young people are difficult to engage in pedagogy may partly reflect the effects of social marginalization, and highlights the need for new forms of engagement (Sloper \& Franklin, 2005). Lefevre (2015) argues that a superficial focus on 'doing' communication with young people is inadequate and social work education must provide learning opportunities that enable deep learning of underpinning knowledges and ethical commitments. This realization informed this research, as we aimed to create audio-bites based on young people's care experiences, to inform social work student's knowledge and skill base in preparation for their direct practice with young people.

\section{Care experienced young people}

In Scotland, an estimated 14,738 children are 'looked after' or 'care experienced' (Children (Scotland) Act, 1995), defined as those in the care of their local authority (Scottish Government, 2018). Children may become 'looked after' for various reasons, including: abuse or neglect; they have disabilities that require special care; they are 'separated children'; or they have been involved in the youth justice system. Children and young people may live in several types of care settings, at home (where a child is subject to a Compulsory Supervision Order), in foster care, residential unit or school, a secure unit, with prospective adopters, or in kinship care i.e. by extended family or close friends. 
Care experienced people are not a homogenous group and many care leavers have positive experiences in care and life generally (Dearden, 2004; Stein, 2008). However, there is evidence to suggest that outcomes for care leavers in terms of mental well- being, educational opportunities, attainment and employment prospects can be much poorer than their noncare peers (Who Cares? Scotland, 2016). As such care experienced children's wellbeing needs are not always achieved. It is essential that social workers have an understanding of some of the key issues that face care experienced young people, and that they use this knowledge to enhance their practice and promote young people's wellbeing. Getting it Right for Every Child (GIRFEC) is the national approach to promote, support and safeguard the wellbeing of children and young people in Scotland. The 'SHANARRI Wellbeing Indicators' of GIRFEC specify that all children should be: safe, healthy, achieving, nurtured, active, respected, responsible, and included. Social work graduates must show they have the requisite skills and knowledge base to uphold children's rights, promote children's wellbeing in line with GIRFEC (Key Capabilities in Childcare and Protection, Scottish Government, 2006).

Recording is a significant part of social work practice. Child's Plans and chronologies form part of the assessment and decision-making processes (Social Work Inspection Agency, 2010). Child's Plans are personalized plans that provide detail about the child's needs, explain what should improve for the child and the actions to be taken, this may include a child protection plan where the child is believed to be at risk of harm (Scottish Government, 2014). The purpose of a chronology is to provide a clear account of all significant events in a child's life to date, drawing upon knowledge and information held by agencies involved with the child and family (Social Work Inspection Agency, 2010). The importance of chronologies have been highlighted in Significant Case Review recommendations (Scottish Government, 2014). Inadequate or inaccurate reporting has resulted in missed opportunities to identify risk of harm to young people and inadequate care provision. There are limited findings about care experienced young people's percep- tions about being 'subjects' of statutory recording practices, such as chronologies and Child's plans, and our research addresses this gap. 


\section{Service user involvement}

Face-to-face service user involvement has been shown to promote dialogue and the development of a 'whole person approach' (Goss \& Miller, 1996), meaning that students recognize that service users are people with problems rather than being defined by their problems (Askheim et al., 2017).

Despite the advantages of $\mathrm{SUCl}$, there are administrative and organizational barriers that restrict or prevent involvement (McLaughlin, 2010; Waterson et al., 2007). Effective and ethical SUCl takes time, effort and a commitment to acknowledge and overcome power imbalances (Hitchin, 2016; Robinson \& Webber, 2013). These issues are pertinent in the context of young people's involvement in social work education, research and practice, given the unequal power imbalance that exists between them and adults (Clark et al., 2005). Involving 'seldom-heard' service users, such as young people, in research and educa- tion requires skillful negotiations between service users, researchers and educators (Hernandez et al., 2008, p. 1). Levy et al. (2016) argue that a broader knowledge base is required that embraces experiential knowledge and is inclusive of marginalized and silent voices.

\section{Technology in social work education}

Technology offers complementary alternatives to face-to-face SUCl with the use of websites, case studies, theater, DVDs, printed and audio-visual materials can be used (Wallcraft et al., 2012; Waterson et al., 2007). Audio resources have been found to change learning from more didactic lecture-based learning to a more constructivist learning practices, which can enrich the quality of teaching and learning experiences (Bryans Bongey et al., 2006) and benefits students by generating deeper student engagement (Lonn \& Teasley, 2009). This research aimed to build on existing SUCl at the University of Stirling by creating audiobites-up to 10 minutes long, based on care experienced people's involvement with social work. Listening to young people is a key social work skill and correspondingly our methodological and theoretical approach was underpinned by a commitment to listening to 
the voices of the young people we interviewed (McLeod, 2007), and the voices of the students and educators who used the audio-bites.

\section{Methodology}

We aimed to develop audio-bites for a social work programme. A co-productive approach was adopted as we worked with members of the University SUCI group, UNITY, who provided guidance and helped to shape the learning output. Our intention was to develop collective understandings to effect change in education and practice (Bell \& Pahl, 2018). UNITY is attended by a core group of 10 adults who have used various social work services and regularly contribute to social work teaching. UNITY could not simply absorb young people into the group without altering the format of meetings, which had proven to be effective for current members, for example, with meetings taking place in the day, which may clash with young people's education or employment commitments. The audio-bites were created in five stages. First, we reviewed literature about the use of technological resources in education to explore different outputs and evaluated different options. Second, we surveyed all students on the qualifying social work programmes (approximately 200 over 4-year groups) to find out what service user and carer input they received and to learn about their learning style preferences. Feedback from six respondents indicated that the inclusion of children and young people's voices was a noticeable gap. In terms of learning, students valued group discussion and space to reflect upon their own values and knowledge.

Third, making use of a co-production methodology (SCIE, 2013) we consulted with UNITY over a period of 8 months and developed a template for the audio-bites design. We designed the research information sheet and interview schedule and shared anonymized transcripts and the audio-bite template. The group's advice was crucial to the development of the output as they drew upon their life experiences, research and teaching experience to suggest meaningful ways to engage with the young people. The fourth stage involved data collection, analysis, script-writing and production. We aimed to identify $6-8$ young people aged $12-18$ and to create eight resources relating to their personal experience of being 'looked after'. This age range was selected to include a wide 
range of experiences across middle and late childhood to illustrate children's various and diverse needs and experiences. We anticipated that the young people's experiences may relate to various issues such as family breakdown, transitions to and from care settings, parental substance misuse, domestic abuse, and involvement with the Children's Hearing (Children's Hearings (Scotland) Act, 2011).

We obtained ethical approval from the University of Stirling and then gained consent from a third-sector organization who support children and young people. The organization distributed the participant information sheet to the young people and helped us to facilitate two interviews with four young people. These young people will be referred to as 'key participants' to emphasize their central role and distinguish them from young actors involved in the voice recording. Key participants were asked for their preference for where the interview took place and whether or not their support worker attended.

Key participants and support workers were given information about the aims and purpose of the research and verbal and written consent was obtained before the interviews began. We checked for informed consent by reviewing together the reasons for creating the resource and how their words would be used. Two interviews of one hour were carried out: one with a key participant and support worker, another with three key participants and support worker. A relatively open interview schedule was followed, which included questions about reasons for coming into contact with social work, experiences of care, challenges faced and hopes for the future. The key participants were remunerated for their participation. To increase the trustworthiness of the data, descriptions of the interviews were written at the end of the interview. The key participants selected a voice actor to represent them after listening to pre-recorded voice clips.

Interviews were transcribed verbatim to capture all discourse between key participants, support workers and interviewer. Both authors carried out thematic analysis by identifying recurrent concepts in all interview transcripts independently, which were then crosschecked in discussion together (see Patton, 1990). These were: the ideal social worker, communication, chronologies, and hopes and dreams. Scripts were developed from reading 
and re-reading interview transcripts. This was an iterative process to ensure fidelity of meaning, whilst creating feasible scripts. Efforts to prevent bias in the script writing process include grouping interview data by theme, rather than changing the words spoken by young people, and keeping the format as conversation (with sometimes overlapping speakers) for to keep the young person's voice. To maintain confidentiality and anonymity of participants in the construction and use of the resource, names of people, places and organizations were changed.

We recorded the audios with young actors (aged 17-21) and a videographer. Whilst original voices and some authenticity was lost in the use of voice actors, this was pragmatic in allowing us to carefully anonymize and protect the identity of key participants in scripts. Prior to recording, scripts were shared with UNITY. We also met with the actors to discuss the research and script to discuss the impact and feelings that arose from role-playing. The recordings were presented to the key participants to check for accuracy and we sought general feedback about the experience of being interviewed. In stage five, the audio-bites were used in a 'Children and Families' module for 40 social work students, and at the end of the module a survey about the audios was administered. Comments from UNITY, the key participants, support workers, educators and actors were collected for evaluation purposes and will be shared later in the article.

\section{Findings}

Four key participants were interviewed about their experiences of social work involve- ment, and the content of these interviews was used to create 8 audio-bites, up to ten minutes long: 4 autobiographical narratives based around their care experience and relationships with social workers, and 4 themed group discussions: The 'ideal' social worker; Communication; Chronologies; Hopes and dreams (see Table 1). Group discussions took place with Liam, Lilly and Beth only, as Simon was based in a different location. 


\section{Table 1: Overview of recordings}

\begin{tabular}{|c|c|}
\hline $\begin{array}{l}\text { Autobiographical } \\
\text { summary/ theme }\end{array}$ & Content \\
\hline Lilly & $\begin{array}{l}\text { Lilly is a white Scottish female, age } 14 \text {. She lives in foster care and } \\
\text { formerly a residential setting. She talks about foster care, what it is like } \\
\text { to attend Children's Hearings, and her difficulties with her current } \\
\text { social worker. }\end{array}$ \\
\hline Liam & $\begin{array}{l}\text { Liam is a white Scottish male, age } 15 \text {, he lives in foster care and } \\
\text { formerly kinship care. He talks about his placements and experiences } \\
\text { of social workers, their values and behaviours. }\end{array}$ \\
\hline Beth & $\begin{array}{l}\text { Beth is a white Scottish female, age } 19 \text {. She lives in independent } \\
\text { housing and was formerly in foster care and a residential care home. } \\
\text { She talks about her experience of leaving care and gaps in support. }\end{array}$ \\
\hline Simon & $\begin{array}{l}\text { Simon is a white Scottish male, age 19. He lives in independent housing } \\
\text { and formerly foster care and a residential care home. He talks about his } \\
\text { experience of living independently and his relationships with } \\
\text { professionals. }\end{array}$ \\
\hline $\begin{array}{l}\text { The 'ideal' social } \\
\text { worker }\end{array}$ & $\begin{array}{l}\text { Group discussion with Liam, Lilly and Beth about the qualities of a social } \\
\text { worker they valued, such as being curious, responsive, experienced, } \\
\text { and comfortable to self-disclose. }\end{array}$ \\
\hline
\end{tabular}




\begin{tabular}{|l|l|}
\hline $\begin{array}{l}\text { Communication } \\
\text { and power }\end{array}$ & $\begin{array}{l}\text { Group discussion about feeling excluded from communication; last } \\
\text { minute changes of plans and information sharing without consent. }\end{array}$ \\
\hline Chronologies & $\begin{array}{l}\text { Group discussion about chronologies, Child's Plans and feeling } \\
\text { powerless about who accesses their records. }\end{array}$ \\
\hline Hopes and dreams & $\begin{array}{l}\text { Group discussion about the young peoples' goals and attitudes, and } \\
\text { actions they feel their social workers could take to help them achieve } \\
\text { their goals. }\end{array}$ \\
\hline
\end{tabular}

\section{The 'ideal' social worker}

All young people had changed placements and had experienced different social workers. The young people discussed the qualities, actions and inactions that made some social workers better than others. There was a sense that less desirable social workers responded to the young people's problems rather than viewing them as unique individuals. Moreover, Simon said that his social worker asked his key worker rather than him about his needs, leaving him feeling disrespected and under-valued.

"You know, when I was younger social work were the enemy too. They were the ones to blame for me getting taken away from mum and dad. It is their fault that I had got taken away and had such a terrible few years. 'Ryan's' [social worker] very difficult to get hold of. He cancels on me last minute. It might be months between meetings when I hear from him ... He only phones me if he has to. Sometimes he will want to speak to me all of a sudden when it is coming up to a meeting or he wants me to sign something. Sometimes I would phone him if I am having a bad day, or have fallen out with someone and I'll get the answering machine. "Hi this is 'Ryan Chesser'". The next day he won't phone me, he'll phone my key worker to check. I feel like saying 'ask me!' don't ask someone else. Phone back" (Simon)

"The only time the social workers came [to the kinship placement] was the times I was 
in trouble, not in huge trouble mind, but when I was they wouldn't really discuss like why maybe I'm feeling like the way I was. They were more discussing what punishment, the consequence, not what made me do it. There was one called 'Anne'. .. Although like ... although she was a really good social worker, I think that . . she was good at writing stuff down on paper and the Child Plan and all that and saying it how she thinks on paper. But I don't think she was good at actually like helping if you know what I mean?" (Liam)

"I'd like my social worker to phone more, come and see me, make an effort, when I call up don't just say like... she's busy or out of the office. Like answer my calls. Return them. Meet regular. I'm not asking like you know once a week but once a fortnight or something at least. I'm getting to see her because l've hardly ever seen her like. She's not spending time with me because she can't like make it because she's rather busy doing ... I phoned her, and she said that she can't come and see me just now because she's got other caseloads and I'm not the top of her priority list. It makes me feel shit. You don't need to be somebody's priority, but actually pay a little attention. Make an effort" (Lilly)

Beth: "We know fuck all about them. Because they don't tell us, like say . . I asked my social worker where does she stay and she was like 'oh I can't tell you that information"'

Lilly: "Just ay an interest." Interviewer: "So actually, care about you?" Lilly: "Yeah. Instead of my bad behaviour"

Positive qualities and actions related to the social workers' availability, that they responded to text messages and phone calls, listened to the young people and took interest in their lives, and interests. For instance, Lilly talked about a social worker taking her out for run to 'clear her head'. The support of an advocate was found to be useful for Simon, to help overcome the power differentials in statutory meetings. 
"When I was younger I used to hate meetings. All of them. I found them intimidating with everyone in their suits and ties. It brought up bad memories, so for a long time I didn't go. But I started going to reviews when I got an advocate. We go to McDonalds beforehand and have a chat. Just the two of us. I open up and tell him what I want. They help me get my feelings off my chest" (Simon)

\section{Communication and power}

The key participants talked about being subjects of statutory processes and practices and some of the injustices they experienced in regards to fulfilling their needs and wishes and exercising their rights. Beth reflected on her experience in a residential unit and said that she had little free time and curfews unfairly varied amongst the young people in the care setting: "I wasn't allowed out after 9 o'clock before I was 17, and now the ones are getting out 'til half ten at night".

Injustices also extended to concern about inappropriate information sharing amongst professionals. Beth said that her Child's Plan was shared with her employer, without her permission and this left her feeling exposed and labelled as a 'looked after' child. Lilly talked about the difficulties she faced when going to statutory meetings, given her estranged relationship with her gran. The social worker suggested that Lilly went to the last fifteen minutes of the meeting, while her gran attended up until that point and was then asked to leave. Lilly said that her gran took offense and got upset with her, meaning that Lilly felt uncomfortable and burdened by the prospect of statutory meetings.

"Child's Plan and like core group meetings and stuff like that. I get invited to the last 15 minutes because my gran goes. She has parental rights. My social worker thinks we should be like together but at the end of the day I should be entitled to go to the meeting because it's about me. I don't see my gran at all. Yeah, so I get invited for like the last 10 minutes and then they're saying 'oh well gran can leave' but then my Nan goes mental at me for saying that I don't want her there. One day I tried to phone her and she was like, 'oh I don't want to speak to you after you not wanting me at your 
meeting'. The last meeting I wasn't invited to because my Nan was there and she has parental responsibility. I don't know how it went" (Lilly)

The accounts from the key participants highlighted difficult experiences, and suggested that the young people's wellbeing needs were not always achieved. They highlighted the significance of events that may be considered 'small things' but contributed to their sense of wellbeing; and if the young people (did not) feel safe, respected, valued, included in meetings, or listened to and they were not always treated as responsible young people, with negative or problematic qualities highlighted, neglecting positive attributes and experiences (Scottish Government, 2015). These findings chime with Ridley et al. (2016) in regards to looked after and care leavers' viewpoints about the importance of consistent, accessible social workers, who take time to listen to their views and concerns. The findings also build upon findings from Rees et al. (2011) whose study showed how social workers balance protection and participation with adolescents, showing times when sharing information (or not doing) lead to feelings of powerlessness.

\section{Social work education}

In this section, we discuss how these findings were used to inform the audio-bites. A series of questions for students accompanied each audio-bite and these were linked to the module learning outcomes, social work codes of practice (Scottish Government, 2006) and the Key Capabilities in Child Care and Protection (Scottish Government, 2006) to prepare students to work with children and young people. For example, after listening to the 'Ideal social worker'

audio-bite, the following questions were displayed, see Figure 1: Audio-bites highlighted the ambiguity and complexity of direct work with 'looked after' children. Students were encouraged to engage in reflexive practice, by thinking about their current knowledge and understanding and their preparation for direct work with young people, in particular thinking about relational practice (Ruch et al., 2010; Winter et al., 2017), and the application of listening skills, sensitive questioning and empathy. This is significant since the social work graduates are required to demonstrate competence to work with children and young people. 
Figure 1: Questions for Students.

1) What qualities do the young people perceive are important in an ideal social worker?

2) What experiences have informed this?

3) Are there any contradictions or tensions between them?

\section{Discussion and evaluation}

A co-productive approach calls for ongoing evaluation (Pemberton \& Mason, 2009) and as such we consulted with key stakeholders (key participants, UNITY members, students and educators) throughout the project; to improve the resource and to maximize opportunities for students' learning and professional development.

Key participants wanted the audio-bites to be shared with senior managers and social workers as well as students. Their desire to be 'listened to' and for action to be taken is indicative of recurring messages from research, namely that young people do not always feel valued or listened to (Boylan et al., 2010; Winter et al., 2017). Moreover, certain groups may be 'overresearched' with limited awareness of the change, if any that arises as a result of research participation (Clark et al., 2005).

The audio-bites provided a learning opportunity for students to hear from young people and to learn from their accounts. Students rated the audio-bites as 'excellent' or 'good' in the online evaluation, and described how they might use learning in their forthcoming practice placement; by way of considering what intervention style of they would take and the 
importance of listening, questioning skills and empathy. The accounts drew attention to the power imbalances young people experienced, and how the accumulation (or not) of actions by their social worker contributed to their feelings of self-worth. Students were required to move from listening to doing, as they were encouraged to respond to questions and by engaging with the task they practiced key social work skills; listening and reflection (Fook, 2002; Lefevre, 2015). Since social workers are often presented with multiple versions of the same events, the young people's accounts required students to critically reflect upon issues about judgment and veracity, in terms of honoring the young people's version of reality, considering why they felt let down and reflecting on what they might choose to do differently in their future practice. This is where a collection of key social work skills such as communication, analysis, recording, and critical reflection are used to produce understandings and to inform decision-making (Taylor \& White, 2001). Social work educators said the audio-bites were a useful way to prompt discussion about young people's lived experiences of social work. Reflecting on what could be done differently; one educator suggested linking questions more explicitly with developmental theory, about young people's internal working models.

Student and educators' feedback indicated that listening to the audios resulted in an emotional connection with the young people's accounts and encouraged them to reflect on how they would make their own judgments in practice, in so doing, promoting deep learning that has the potential for transferability for professional development. Thus, the process of engaging with the audio-bites has the potential to give students insight into the assessment process to inform their professional development. As Oliver (2010) argues, listening to care experienced young people is not enough; they deserve action to be taken to improve practice responses.

UNITY members said the audio-bites were both powerful and upsetting. One member said she was disappointed that today's young people were going through the same difficulties that she had experienced decades earlier when she was taken into care, and she was upset that seemingly progress had not been made. McLaughlin (2010) recognizes that it can powerful to hear the results of research from those who have directly experienced particular services and experiences. It is disappointing that the findings did not report overwhelmingly positive experiences for the key participants, which may have given the current group members some 
indication that improvements in practice were evident. Audio-bites offer a way to create learning opportunities for students to learn from young people. One strength of the audio-bites, as identified by students and educators, was the narrative approach, particularly in relation to the key participant's biographical accounts. Listening to personal stories has the potential to provide students with insight into individual's and group experiences; values, beliefs, customs, expectations and behaviors (Carter-Black, 2013), which have the potential to inform and transform students' professional practice (Hughes, 2017).

\section{Limitations}

Retaining the words spoken by the key participants meant the audio-bites were powerful and evocative; however, the use of actors inevitably altered the key participants' individualized linguistic repertoire, resulting in variation in dialect, tone, volume and pitch. However, following Matthews (2007) we maintain that young people's voices can be 'more powerful' than adults' voices in sharing experiences about matters that affects them. Moreover, the inclusion of young people's perspectives is indicative of the broader aims of our research, to redress power differentials and to promote children's voices (Gallagher et al., 2012). Audio resources by design provide a one-way outlet, and preclude opportunities for interactions between the subject and listener, or for questions to be addressed (Mason \& Rennie, 2008). The use of 'on-demand' pedagogical audios, such as podcasts have also been criticized for their potential commodification of teaching and learning (Fernandez et al., 2009), meaning that knowledge may not be treated as a personal and valued part of the lived experience. These audio-bites were considered an effective way to bridge service-user involvement with young people. They offered a temporary measure to include young people's experience in the social work programme (BA (Hons) and MSc/PG Diploma Social Work degrees); with the view to build relationships and meaningful involvement with young service users and their support organization young service users in the design and delivery of social work curricula.

\section{Conclusion}

In this article we have presented care experienced young people's perceptions about social work involvement and outlined the stages of co-producing audio-bites to fill a gap in the 
service-user involvement of young people within a social work programme. We evidenced the importance of events in social work that may be considered 'small things' such as information sharing that contribute critically to young people's sense of wellbeing. Real-life narratives presented through audio-bites offer potential benefits to students, educators and the service users themselves to complement face-to-face involvement. 


\section{Acknowledgments}

Thank you to the young people who took time to speak with us and helped us to create this resource, we hope we did your words justice and that the next generation of social workers will use your experiences to improve their practice. Thanks to UNITY, the service user and carer group, at the University of Stirling for supporting this project and for the continued expertise you share with students and educators alike.

\section{Disclosure statement}

No potential conflict of interest was reported by the author(s). Funding This project was made possible by a donation from Mr and Mrs Ward, in memory of their daughter, Nancy Ward, who studied on the Social Work programme at the University of Stirling. Funding was also received from the Innovation Fund, University of Stirling. 


\section{References}

Askheim, O. P., Beresford, P., \& Heule, C. (2017). Mend the gap - Strategies for user involvement in social work education. Social Work Education, 36(2), 128140. https://doi.org/10.1080/02615479.2016.1248930

Bell, D. M., \& Pahl, K. (2018). Co-production: Towards a utopian approach. International Journal of Social Research Methods, 21(1), 105117. https://doi.org/10.1080/13645579.2017.1348581

Boylan, J., Dalrymple, J., \& Ing, P. (2010). Let's do it! Advocacy, young people and social work education. Social Work Education, 19(6), 553563. https://doi.org/10.1080/02615470020002290

Bryans Bongey, S., Cizadlo, G., \& Kalnbach, L. (2006). Explorations in course-casting: Podcasts in higher education. Campus-wide Information Systems, 23(5), 350-367. doi:10.1108/10650740610714107

Carter-Black, J. (2013). Teaching cultural competence: An innovative strategy grounded in the universality of storytelling as depicted in African and American storytelling traditions. Social Work Education, 43(1), 35-50. doi:10.5175/JSWE.2007.200400471 Children and Young People (Scotland) Act. (2014). c. 8. Retrieved June 27, 2019 from http://www.legislation.gov.uk/asp/2014/8/contents/enacted

Children's Hearings (Scotland) Act. (2011). c. 1. Retrieved June 27, 2019 from https://www. legislation.gov.uk/asp/2011/1/contents

Clark, M., Lester, H., \& Glasby, J. (2005). From recruitment to dissemination: The experience of working together from service user and professional perspectives. In L. Lowes \& I. Hulatt (Eds.), Involving service users in health and social care research (pp. 85-93). Routledge.

Dearden, J. (2004). Resilience: A study of risk and protective factors from the perspective of 
young people with experience of local authority care. Support for Learning, 19(4), 187193. https://doi. org/10.1111/j.0268-2141.2004.00346.x

Fernandez, V., Simo, P., \& Sallan, J. M. (2009). Podcasting: A new technological tool to facilitate good practice in higher education. Computers \& Education, 53(2), 385392. https://doi.org/10.1016/i.compedu.2009.02.014

Fook, J. (2002). Social work: Critical theory and practice. Sage Publications Ltd. Gallagher, M., Smith, M., Hardy, M., \& Wilkinson, H. (2012). Children and families' involvement in social work decision making. Children and Society, 26(1), 7485. https://doi.org/10.1111/j.1099-0860.2011.00409.x

Goss, S., \& Miller, C. (1996). From margin to mainstream: Developing user-and carer-centred community care. Joseph Rowntree Foundation.

Grant, S., McCulloch, P., Kettle, M., Sheridan, L., \& Webb, S., (2017). Newly qualified social workers in Scotland: A five-year longitudinal study. Scottish Social Services Council, Interim Report: December 2017.

Hernandez, L., Robson, P., \& Sampson, A. (2008). Towards integrated participation: Involving seldom heard users of social care services. British Journal of Social Work, 40(3), 1-39. doi:10.1093/bjsw/bcn118

Hitchin, S. (2016). Role-played interviews with service users in preparation for social work practice: Exploring students' and service users' experience of co- produced workshops. Social Work Education, 35(8), 970-981. https://doi.org/10.1080/02615479.2016.1221393

Hughes, M. (2017). What difference does it make? Findings of an impact study of service user and carer involvement on social work students' subsequent practice. Social Work Education, 36(2),203-216. https://doi.org/10.1080/02615479.2016.1274725

Lefevre, M. (2015). Becoming effective communicators with children: Developing practitioner 
capability through social work education. British Journal of Social Work, 45(1), 204-224. https://doi.org/10.1093/bjsw/bct109

Levy, S., Aiton, R., Doig, J., Dow, J. P. L., Brown, S., Hunter, L., \& McNeil, R. (2016). Outcomes focused user involvement in social work education: Applying knowledge to practice. Social Work Education, 35(8), 866-877. https://doi.org/10.1080/02615479.2016.1240160

Lightfoot, J., \& Sloper, P. (2003). Having a say in health: Involving young people with a chronic illness or physical disability in local health services development. Children and Society, 17(4), 277-290. https://doi.org/10.1002/chi.748

Lonn, S., \& Teasley, S. D. (2009). Podcasting in higher education: What are the implications for teaching and learning? Internet and Higher Education, 12(2), 8892. https://doi.org/10.1016/j.iheduc.2009.06.002

Mason, R., \& Rennie, F. (2008). E-learning and social networking handbook: Resources in higher education. Routledge.

Matthews, S. H. (2007). A window on the 'new' sociology of childhood. Sociology Compass, 1(1),322-334. https://doi.org/10.1111/j.1751-9020.2007.00001.x

McLaughlin, H. (2010). Keeping service user involvement in research honest. British Journal of Social Work, 40(5), 1591-1608. https://doi.org/10.1093/bjsw/bcp064

McLeod, A. (2007). Whose agenda? Issues of power and relationship when listening to looked-after young people. Children and Family Social Work, 12(3), 278-286. https://doi.org/ 10.1111/j.1365-2206.2007.00493.x

Oliver, K. (2010). Children's views and experiences of their contact with social workers: A focused review of the evidence. Children's Workforce Development Unit. Retrieved June 27, 2019from https://dera.ioe.ac.uk/11515/1/Children s views and experiences of contact with_social_workers_report_July_2010.pdf 
Patton, M. Q. (1990). Qualitative research and evaluation methods. SAGE Publications. Pemberton, S., \& Mason, J. (2009). Co-production and sure start children's centres: Reflecting upon users', perspectives and implications for service delivery, planning and evaluation. Social Policy and Society, 8(1), 13-24. https://doi.org/10.1017/S1474746408004545

Rees, G., Hicks, L., \& Gorin, M. (2011). Adolescent neglect: Research, policy and practice. Jessica Kingsley Publishers.

Ridley, J., Larkins, C., Farrelly, N., Hussein, S., Austerberry, H., Manthorpe, J., \& Stanley, N. (2016). Investing in the relationship: Practitioners' relationships with looked-after children and care leavers in social work practices. Child and Family Social Work, 21(1), 5564. https://doi. org/10.1111/cfs.12109

Robinson, K., \& Webber, M. (2013). Models and effectiveness of service user and carer involvement in social work education: A literature review. British Journal of Social Work, 43(5), 925-944. https://doi.org/10.1093/bjsw/bcs025

Ruch, G., Turney, D., \& Ward, A. (2010). Relationship-based social work: Getting to the heart of practice. Jessica Kingsley.

SCIE. (2009). Building user and carer involvement in social work education. Retrieved June 16, 2019 from https://www.scie.org.uk/publications/ataglance/ataglance19.asp

SCIE. (2013). Coproduction in social care: What it is and how to do it. Retrieved June 16, 2019 from https://www.scie.org.uk/publications/guides/guide51/

Scottish Executive. (2003). The framework for social work education in Scotland. The Stationery Office.

Scottish Government. (2006). Key capabilities in child care and child protection. Retrieved June 28, 2019 from https://www.gov.scot/publications/key-capabilities-child-careprotection/ 
Scottish Government. (2014). National guidance for child protection in Scotland. Retrieved June 26, 2019 from https://www2.gov.scot/Resource/0045/00450733.pdf

Scottish Government. (2015). Getting it right for looked after children and young people: Early engagement, early permanence and improving the quality of care. Retrieved June 26, 2019 from https://www.gov.scot/binaries/content/documents/govscot/publications/strategyplan/2015/11/getting-right-looked-children-young-people-strategy/documents/00489805pdf/00489805- pdf/govscot\%3Adocument/00489805.pdf

Scottish Government. (2018). Children's social work statistics Scotland, 2017-18. Retrieved June 26, 2019 from https://www.gov.scot/publications/childrens-social-work-statistics$\underline{2017-2018 /}$

Sloper, P., \& Franklin, A. (2005). Listening and responding? Children's participation in health care within England. International Journal of Children's Rights, 13(1), 1129. https://doi.org/10. 1163/1571818054545277

Social Work Inspection Agency. (2010). Practice guide: Chronologies. Retrieved June 26, 2019 from https://www.webarchive.org.uk/wayback/archive/20180521060542mp /http://www. gov.scot/ Resource/Doc/299703/0093436.pdf

Stein, M. (2008). Resilience and young people leaving care. Child Care in Practice, 14(1), 3544. https://doi.org/10.1080/13575270701733682

Taylor, C., \& White, S. (2001). Knowledge, truth and reflexivity: The problem of judgement in social work. Journal of Social Work, 1(1), 3759. https://doi.org/10.1177/146801730100100104

The Scottish Office Social Work Services Group (1997). Scotland's Children: The Children (Scotland) Act 1995, Regulations and Guidance, Volume 1: Support and Protection for Children and their Families. Edinburgh: The Stationery Office. 
Wallcraft, J., Fleischmann, P., \& Schofield, P. (2012). The involvement of users and carers in social work education. Social Care Institute for Excellence. Retrieved June 26, 2019 from https://www.scie.org.uk/publications/reports/report54.pdf

Waterson, J., Morris, K., Waterson, J., \& Morris, K. (2007). Training in 'social' work: Exploring issues of involving users in teaching on social work degree programmes. Social Work Education,24(6), 653-675. https://doi.org/10.1080/02615470500185093

Who Cares? Scotland. (2016). Outcomes for care experienced children and young people.

$\begin{array}{llll}\text { Retrieved } & 2019\end{array}$ from http://www.parliament.scot/General\%20Documents/CEYP_outcomes 06.16.pdf

Winter, K., Cree, V., Hallett, S., Hadfield, M., Ruch, G., Morrison, F., \& Holland, S. (2017). Exploring communication between social workers, children and young people. British Journal of Social Work, 47(5), 1427-1444. https://doi.org/10.1093/bjsw/bcw083 